$12-2014$

\title{
Enduring Temptation: The Structure and Coherence of the Letter of James
}

Matt A. Jackson-McCabe

Cleveland State University, m.jacksonmccabe@csuohio.edu

Follow this and additional works at: https://engagedscholarship.csuohio.edu/clphil_facpub

Part of the Biblical Studies Commons, Christianity Commons, and the History of Christianity

\section{Commons}

How does access to this work benefit you? Let us know!

\section{Publisher's Statement}

Copyright Sage Journals 2014. This article first appeared in Journal for the Study of the New Testament, vol. 37, no. 2, 2014, pp. 161-184. http://journals.sagepub.com/doi/abs/10.1177/ $0142064 \times 14554753$

\section{Original Citation}

Jackson-McCabe, M. "Enduring Temptation: The Structure and Coherence of the Letter of James." Journal for the Study of the New Testament, vol. 37, no. 2, 2014, pp. 161-184.

This Article is brought to you for free and open access by the Philosophy \& Comparative Religion Department at EngagedScholarship@CSU. It has been accepted for inclusion in Philosophy \& Comparative Religion Department Faculty Publications by an authorized administrator of EngagedScholarship@CSU. For more information, please contact library.es@csuohio.edu. 


\title{
Enduring Temptation: The Structure and Coherence of the Letter of James
}

\author{
Matt Jackson-McCabe
}

\begin{abstract}
The extent to which there is a deliberate compositional structure governing the letter of James is an open question among contemporary interpreters. This article argues that a complementary consideration of formal textual features, thematic content and rhetorical function shows that the letter was composed as a unified, coherent treatment of the ethical implications of its underlying logos/desire dichotomy. Framed generally as a matter of enduring temptation in humble dependence on a provident deity, the letter presents the practical consequences of birth with logos under three headings: doing the works of the 'law of freedom', bridling the tongue, and manifesting a gentle disposition.
\end{abstract}

\section{Keywords}

Anger, desire, law of freedom, logos, speech, temptation

The extent to which the letter of James is a coherent composition has been an issue since Luther pointedly characterized it as 'a few sayings from the disciples of the apostles' that had been 'tossed ... off on paper' (Bachman 1960: 397). ${ }^{1}$

1. An earlier version of this paper was presented at the 2012 Annual Meeting of the Society of Biblical Literature. I am grateful to Duane Watson and Peter Davids, co-chairs of the Letters of James, Peter and Jude Section for the invitation that led me to write it, and to the participants in the session for a very helpful dialogue. Special thanks are also owed to Dale Walker for his careful reading and comments on a subsequent draft. 
Implicit in this characterization are two claims that, having become formal and sustained theses in the enormously influential commentary of Martin Dibelius (1988 [1921]), have been central to academic discussion of the letter ever since. The first is that the text is a sort of post-classical compendium of words of past worthies rather than the composition of an author who was a creative intellect in his own right. In Dibelius's commentary (1988: 11) this view was developed into a thesis that the letter, as a mere 'treasury' of sayings material of diverse origin, has no theological coherence. ${ }^{2}$ The second is that the collector assembled these materials with little concern to put them in any meaningful order - a claim that Dibelius (1988: 1-11 and passim) formalized by classifying James as paraenesis, and one that he pursued relentlessly, section by section and line by line, in his commentary.

The claim that James is devoid of a coherent theological vision has been thoroughly refuted. ${ }^{3}$ Even those who continue to interpret the letter as a collection now acknowledge that 'it is virtually indisputable that there is more continuity of thought and more thematic coherence than Dibelius could see' in it, and suggest that the supposed collection consists of sayings from a single person or 'school' (Bauckham 1999: 61-62). ${ }^{4}$ The question of its literary character, on the other hand, remains at the forefront of current scholarly debate.

To be clear, Dibelius did not argue that James is entirely devoid of organization. Like other interpreters, he recognized that the text consists of a series of clear section divisions. His argument, rather, was that there is little or no meaningful structure beyond those broad divisions. As Dibelius (1988: 1 [1921: 1]) saw it, most of these sections consist of various 'self-contained units' of traditional material grouped together thematically or by superficial catchwords to form more (Spruchreihen: 1.2-18; 1.19-27; 5.7-20) and less (Spruchgruppen: $3.13-4.12$; 4.13-5.6) loosely organized compendia on various topics. These mini sayings collections, he said (1988: 1), were themselves compiled similarly loosely around three 'treatise-like expositions' (abhandlungsartigen Ausführungen $)^{5}$ that Dibelius identified as the 'core' (Kernstück) of the work, namely $2.1-13,2.14-26$ and 3.1-12. While showing more deliberate internal development than the rest of the letter, even these expositions were ultimately

2. According to Dibelius (1988: 21 [emphasis his]), 'Ja[me]s has no "theology"'. It is unified only by an 'ethos' that informs its selection and amplification of traditional materials; see further Dibelius 1988: 2, 47-50.

3. For surveys of scholarship on the issue, see Davids 1980: 97-103; 1988: 3640-45; Konradt 1999: 54-78; Penner 1999: 257-308; Jackson-McCabe 2003: 701-706; Batten 2009: 54-64.

4. Compare the conclusion of Davids (1982: 12-13): 'the epistle is very likely a two-stage work. The first stage is a series of Jewish Christian homilies, sayings, and maxims ... The second stage is the compilation of an epistle by editing these pieces together into a whole ... James the Just could well be the author of the first set of materials.'

5. The translation is in this case mine. 
said to 'contain nothing other than expansions of paraenetic sayings' (1988: 3); in this sense they are 'not unrelated in character to the surrounding sayings and groups of sayings' ${ }^{6}$ With the partial exception of these 'treatises', then, even to look for logical development within the larger sections, let alone between them, is fundamentally to misunderstand the text's nature as a 'deposit of tradition' (Dibelius 1988: xii).

Few, if any, would endorse this view today, at least in this stark form. Detailed analyses of the individual sections of the letter in light of Hellenistic rhetoric and ethics have revealed logical coherence and progressions of thought that go far beyond a mere 'expansion of sayings'. This goes not only for what Dibelius considered the 'treatise-like expositions' of 2.1-13, 2.14-26 and 3.1-12 (Watson 1993a; 1993b; cf. Wachob 2000), but also for 3.13-4.10 (Johnson 1983), which he interpreted as a 'group of sayings'. The letter, in short, 'is now understood to be a more structured and rhetorically sophisticated text than Dibelius believed' (Batten 2009: 26). Indeed, most interpreters would extend this judgment beyond the individual sections of the text to argue that the letter as a whole exhibits a deliberate, carefully composed structure. ${ }^{7}$ The current problem, in fact, is precisely an overabundance of such competing arguments.

Some have argued that the overall structure of James is governed by rhetorical categories. This approach is potentially problematic in theory, given the fact that James is a letter rather than a speech $;^{8}$ and the significantly different rhetorical outlines that have been generated are in any case a problem in practice. ${ }^{9}$ More common have been attempts to account for James's structure in thematic terms, often by appealing to some or all of Jas 1 as foreshadowing particular themes and concepts to be developed in the main body (esp. Francis 1970; cf. Davids 1982: 24-27; Reese 1982; Crotty 1992; Taylor and Guthrie 2006; Watson 2007: 112-13). But this approach has produced even more varied results than the rhetorical one, resulting in a dizzying array of outlines built around thematic parallelisms, inclusios, binary oppositions and

6. According to Dibelius (1988: 38), even these 'treatises' include 'ever-present reminders that ... [the author] was not an originator but a transmitter of materials'.

7. Compare the observation of Penner 1999: 272: 'This quest for structure and coherence [in the Letter of James], although manifested in different ways, arises out of the unanimous conviction in current scholarship that such coherence can be found'; cf. Taylor 2004: 112.

8. Cf. the general formulation of the problem by Reed (1997: 182): 'the standard epistolary components ... share some similarity with the four principal parts of rhetorical arrangement ... But the similarity is only functional, not formal ... The similarities may be explained by the fact that language is often used pragmatically in different genres to do similar things.'

9. Compare the outlines in Wuellner 1978 (followed with minor variation in Elliott 1993) with Thurén 1995 and 1997: 592-96, and further the two different proposals made in Baasland 1988 and 1992, respectively. Watson (2007: 1-4), who is otherwise disposed to finding rhetorical patterns of argumentation in James, finds these studies unconvincing. 
chiasms purportedly structuring the letter (Fry 1978; Baasland 1982; Cargal 1993; Tollefson 1997; further Taylor 2004: 90-103; Batten 2009: 9-15). If 'many are convinced that ch. 1 holds the key to the letter's structure' (Taylor 2004: 112), there is little agreement, to put it mildly, on either the shape of that key or what exactly it is unlocking.

Not surprisingly, the varying results of these analyses have begun to produce something of a backlash. Thus Richard Bauckham (1999: 61): 'After so much discussion [of James's structure], there seems to be not even the beginnings of a consensus. One suspects that something must be wrong with the goal that is being attempted.' To be sure, Bauckham (1999: 69-73) agrees that Jas 1 serves to introduce themes that will appear later in the letter. Wary, however, of the idiosyncratic and sometimes arcane outlines that have resulted from rhetorical and thematic approaches, he emphasizes the importance of focusing on 'the kind of literary structure' that actually 'helps readers to read' (1999: 63); the kind, that is, that is signaled by 'reasonably clear formal markers as well as steps or changes in theme or argument'. In Bauckham's view (1999: 66), attention to such overt textual signals leads to the conclusion that James consists of a series of 'selfcontained entities with strong indications to the reader that they are to be read as such'.$^{10}$ It leads, in other words, to a modified form of Dibelius's literary analysis of James as 'compendium'. ${ }^{11}$

Bauckham's methodological concerns are no doubt justified. But is his conclusion correct? Mark Taylor's (2004: 112) recent review of scholarship rightly concludes that '[a]ny convincing analysis' going forward 'will need to [both] take seriously the surface syntactical structure in the text itself and demonstrate how the major themes of perfection, law, judgment, speech and action in James work together'. My intention in this article is to do precisely that. I have argued at length elsewhere (Jackson-McCabe 2010) that James's theological coherence centers on a typically Hellenistic opposition between logos and desire. In what follows I shall argue that a complementary analysis of formal textual features and thematic content, informed by consideration of rhetorical function, shows that this same opposition is central to its literary structure as well. ${ }^{12}$ The letter of James is not a compendium of isolated traditional materials. It is a coherent appeal to endure temptation in humble reliance on a provident deity, elaborated particularly with respect to the three broad areas of good deeds, control of speech and a gentle disposition.

10. Note, though, that this does not prevent Bauckham $(1999: 64,70)$ from offering, however tentatively, a quite subtle structural proposal of his own based around the number 12 .

11. See Bauckham 1999: 67: 'a compendium of wisdom instruction on a varied range of topics'; further Taylor 2004: 105-107.

12. Cf. the methodological approach in Cheung 2003: 58. 


\section{The Structure of James I}

As noted above, there is a fairly wide consensus among contemporary interpreters that some or all of Jas 1 functions to introduce the main themes to be addressed in the body of the letter. What is not agreed is how exactly it does this, much less how the chapter itself is organized. Bauckham (1999: 70), warning against 'obscuring the aphoristic nature of the material by supplying trains of thought which are not expressed', divides it into 12 separate sections. He concedes, however, that the textual signals supporting this division are in this case rather less apparent than those on which he relies elsewhere in the letter. In fact the majority of the letter's interpreters have found Jas 1 to fall rather naturally into broader section divisions. Dibelius (1988: 69-71, 108-109) himself thought it quite obvious that 1.2-18 and 1.19-27 represented textual units, despite denying any logical connection either between them or within them. This same basic division has been recognized by many others, even as interpretations of the character of the sections and their relationship to one another and to the remainder of the letter have differed (e.g., Fry 1978: 430; Baasland 1982: 122; Thurén 1995: 269-73, 277-78; 1997: 593-94; Tollefson 1997: 66; Edgar 2001: 138-67; Cheung 2003: 82; cf. Frankemölle 1990: 175-85; Klein 1995: 38-39). Others have sensed an important division at Jas 1.12, whether within a double introduction in Jas 1 (esp. Francis 1970; cf. Davids 1982: 24-27; Reese 1982; Crotty 1992; Taylor and Guthrie 2006; Watson 2007: 112-13; cf. Tsuji 1997: 63-72; Burchard 2000: 12-13) or with 1.2-12 alone as the letter's introduction (von Lips 1990: 412-24; Konradt 1998: 19-21, 311-12).

The recurring discovery of these same divisions across otherwise varying interpretations is scarcely accidental. Both 1.12 and 1.19 do in fact represent important transitions in the text. What is more, the units they help to define were not intended to be read in isolation from one another, but as transitions within a larger, unified section. James 1.2-12 and 1.13-18 represent two phases of a coherent treatment of the theme of temptation, while 1.19-27 enumerates the practical consequences of it.

\section{James 1.2-18: Enduring Temptation}

If we begin by seeking the sort of textual signals of literary structure that Bauckham emphasizes, the first thing that jumps out is the recurrence of the direct address to 'my [beloved] brothers' in 1.2, 16, 19. As has frequently been observed (e.g., Bauckham 1999: 64; Cheung 2003: 71; Varner 2011), this address often signals the beginning of new sections in James, as it obviously does in 1.2 (cf. 2.1; 3.1; $4.11 ; 5.7)$. However, the fact that it is also used repeatedly to signal transitions or points of emphasis within sections $(2.5,14 ; 3.10$; cf. 5.7-20, passim $)$ means that its function in 1.16 and 1.19 can only be determined by looking for other signals 
within Jas 1. As will be argued fully below, there are indeed strong reasons for seeing 1.19 as the beginning of a distinct literary unit, albeit one with a close relationship to what precedes it. For the moment, then, I will concentrate on 1.16.

James 1.16-17 cautions the 'brothers' about being 'deceived'-specifically

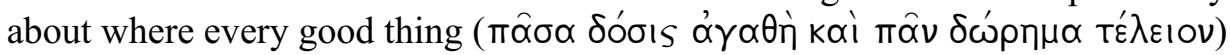
comes from, which according to the text is from a perfectly consistent and

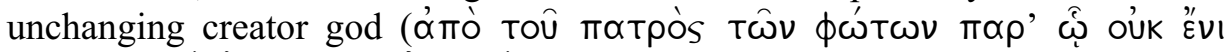

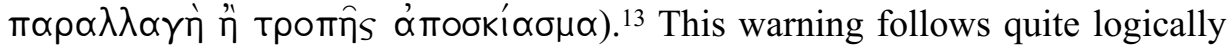
from the two interrelated points made immediately preceding it in 1.13-15: that this God has nothing to do with temptation, and that the real source of temptation is rather human $\varepsilon \pi ı \theta u \mu \dot{i}^{\prime} \alpha$. Having associated $\varepsilon \pi ı \theta u \mu \dot{i}^{\prime} \alpha$ with a seduction that in reality yields only sin and death in 1.14-15, the text warns its audience in 1.16 not to be deceived about whence any good thing really comes. Similarly, the insistence on the consistency and unchangeableness of the creator as said source in 1.17 resonates strongly with the extraordinary assertion in 1.13 that God 'tempts no one' ${ }^{14}$ The immediately following point in 1.18 regarding the manner in which God 'bore us' further underscores the contrast. His will for humanity is

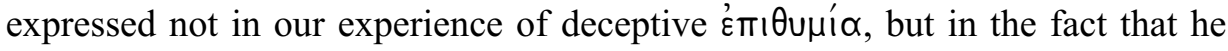
'bore us' with a logos of truth (1.18). The logical development from 1.13-15 to 1.16-18, then, makes clear that the direct address to the 'beloved brothers' in 1.16 serves not to signal a section division, but to emphasize and solemnify the key point that the ultimate source of temptation, sin and death is not God, but rather human desire. ${ }^{15}$

How, if at all, then, does 1.13-18 relate to the preceding 1.2-12? Most significant in this respect is what is most immediately obvious: the theme of

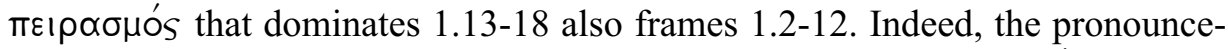

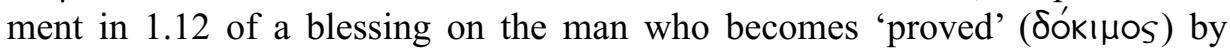

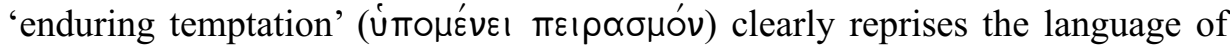

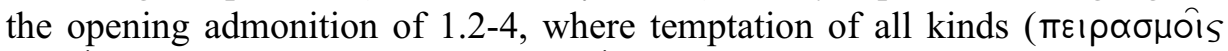

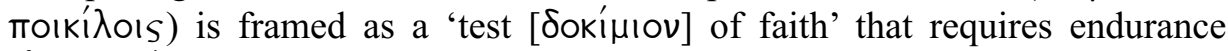

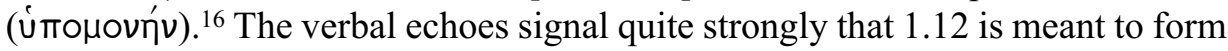
a sort of inclusio with 1.2-4; and that signal is only further reinforced by the

13. For what follows, see further Jackson-McCabe 2010: 196-216.

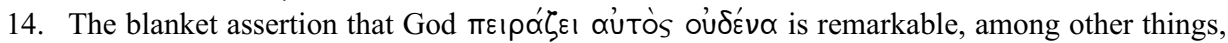

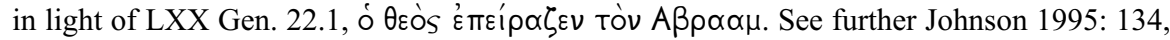
193, 203-204; also Kloppenborg 2010: 66-67, who explains James's departure from Judean literature on this matter as the result of Greek philosophical influence.

15. Cf. 2.5, where an address to the 'brothers' functions similarly to mark emphatically the articulation of a key theological principle.

16. Compare even Dibelius 1988: 88: "The saying [of 1.12] obviously belongs to the theme touched upon in 1:2-4; therefore, "to endure trial" is to be understood in the same sense as "trials" and "endurance" in 1:2 and 1:3'. 
letter's general tendency, noted by Bauckham (1999: 65-66), to use aphoristic statements such as the one in 1.12 to 'round[] off or sum[] up' units of text. ${ }^{17}$

Dibelius (1988: 69) himself found it obvious that 1.2-18 as a whole represented 'a section which in a definite respect forms a complete unit' on the theme of temptation. Guided by his literary model, however, he argued that this unity was entirely superficial, built simply around a catchword, $\pi \varepsilon ı \rho \propto \sigma \mu o ́ s$, that meant different and unrelated things from line to line: "For the temptations whose origins are discussed in 1:13-15 are not the "trials" in 1:2 .. [W] hile these must be dangers from without, 1:13-15 deals with dangers of the inner life'; 'the seduction by lusts in vv. 13-15 has nothing whatsoever to do with the afflictions in v. 12' (1988: 71, 90). Any attempt to find meaningful connection between them was thus 'categorically denied' (Dibelius 1988: 70).

The wedge that Dibelius drove between 1.2-4, 12 and 1.13-15 is more a product of his atomistic model than a compelling argument for it. The notion that 'external dangers' and 'dangers of the inner life' can have nothing to do with one another is quite alien to Hellenistic ethics; indeed, the quintessential illustration selected to demonstrate reason's mastery of the passions in 4 Maccabees is precisely the Maccabean martyrs' endurance of torture (Jackson-McCabe 2010: 95-105). ${ }^{18}$ Analysis of 1.2-12 in light of 1.13-18, in fact, reveals a coherence of thought that goes well beyond a mere repetition of catchwords.

It is to be noted, in the first place, that the inclusio about resisting temptation in $1.2-4,12$ provides a direct and complementary parallel to what is said about the failure to so resist in 1.13-18. In the latter passage, giving in to temptation is said to produce 'sin' and lead ultimately to 'death'. In 1.2-4, 12, on the other hand, the endurance of temptation is said to produce a 'perfect ergon' (1.24) - a highly charged ethical concept in James - and to lead ultimately to the 'crown of life' (1.12). Taken together, then, the two sections present the two possible outcomes of temptation-resisting or not resisting - in directly contrasting sequences moving from type of action produced as immediate result (perfect ergon or sin) to long-term, eschatological consequences (crown of life or death). ${ }^{19}$

It is all the more striking, then, that both sections place particular emphasis on the providential character of the deity. As already noted, in 1.13-18 the problem of temptation is precisely the seductive character of $\varepsilon \pi\left(\theta u \mu\right.$ i $^{\alpha}$; resisting temptation is in this sense a pragmatic issue of not being 'deceived' as to where any

17. So also von Lips 1990: 414.

18. Compare Kloppenborg 2010: 54-70, where 1.2-4 and 12-15 are analyzed together as an elaboration of a Jesus saying (cf. Q 6.22-23) informed by Hellenistic philosophy.

19. Whether or not the etiological myth of Gen. 2-3 lies in the background, the 'death' of 1.15

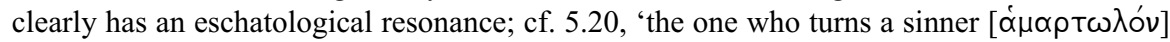

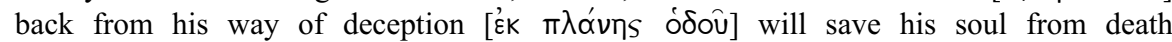

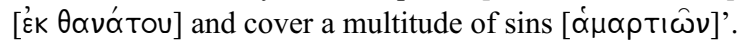


truly good thing really comes from. Similarly, the assurance in 1.2-4 that the one who endures temptation will 'lack nothing' ( $\varepsilon \nu \mu \eta \delta \varepsilon v i$ ' $\lambda \varepsilon ı$ เ in 1.5-8 by a discussion of exactly who should — and who should not - expect to be a beneficiary of 'the God who gives to all simply and unbegrudgingly' (1.5,

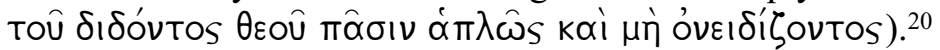

Attention to the interrelation of these two themes, $\pi \varepsilon 1 \rho \alpha \sigma \mu \operatorname{s}^{\prime}$ and providence, goes a long way towards illuminating the progression from thought to thought in the intervening lines between 1.2-4 and 1.12. If it requires a certain wisdom to endure temptation (1.5), ${ }^{21}$ a key part of that is a recognition that good things will ultimately come only from humble reliance on the deity, not from following one's own desires. Temptation is in this sense framed as a 'test of faith' (1.3) specifically, faith that the deity will in fact provide; that those who withstand the allure of temptation will nonetheless, as the text says, lack nothing (1.4). Insofar as this principled assertion might seem to run counter to actual human experience, the text proceeds to issue a caveat. Even asking God will be ineffective, it says, if unaccompanied by sufficient faith (1.6). The diquxos who vacillates between faith and doubt - and thus between deceptive $\varepsilon$ mi $\theta u \mu^{\prime} \alpha$ and the logos of truth, sin and erga-stands precariously between death and life, and should expect nothing from God (1.7-8).

The subsequent exhortation to 'the humble brother' to boast in his coming exaltation (1.9), particularly when paired with a taunting call for 'the rich one' to anticipate his pending 'humiliation' (1.10), serves to reinforce these assertions in the face of socio-economic realities that might otherwise seem to belie them. The apparent success of 'the rich' and their schemes, the text insists, is only temporary. The 'humble brother' is encouraged to reassure himself with 'boasts' about an inevitable reversal that will finally see these rich destroyed and himself, having become 'proved' by resisting temptation, 'exalted' and given a 'crown of life' (1.11-12).

In sum, Jas 1.2-18 represents a coherent treatment of the problem of temptation, in two phases. James 1.2-12 asserts the importance and rewards of enduring

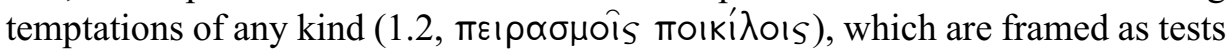
of faith in divine providence. James 1.13-18, conversely, issues a warning about the power and consequences of human desire, which can seduce one away from reliance on the provident God and toward sin and death.

20. On the force of this description of God, see Johnson 1995: 179-80: 'The giving of God, in other words, is universal, unequivocal, and generous'.

21. Cf. Kloppenborg 2010: 41: 'in this respect James belongs to the same orbit as the Wisdom of Solomon and 4 Maccabees which likewise privilege the possession of wisdom (and the benefits that flow from this), in particular as the way to endure adversity and persecution'. 


\section{James 1.19-27:The Practical Consequences of Birth with Logos}

James 1.19 is marked by yet another direct address to the 'beloved brothers', this time to introduce a three-part admonition about being 'quick to hear, slow to speak, and slow to anger'. With 2.1 universally recognized as the beginning of a new argumentative section, the question to be addressed is how to understand 1.19-27 both in itself and in relation to what precedes and follows it.

The internal structure of the section is actually quite plain. Though inexplicably ignored by subsequent interpreters, Dibelius (1988: 108-109) correctly recognized that 1.19-27 is framed around the three-part admonition of 1.19, which invokes a proverbial grouping of 'quick to hear', 'slow to speak' and 'slow to anger'. ${ }^{22}$ The final element of the traditional set, 'slow to anger', is picked up first in 1.20-21. After a warning that 'human anger does not produce God's right-

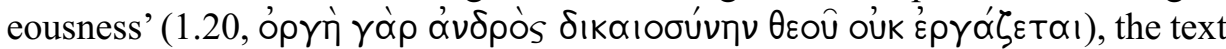
issues a call for the 'filthy excess' here associated with anger to be 'set aside' so that the 'implanted logos' can be received instead with mpoütms, 'gentleness' (1.21) - a standard antonym of ópy' in the Hellenistic literature (Walker 2002: 53-62, 336-40). The admonition 'quick to hear' then provides the jumping off point for a reminder in 1.22-25 about not just 'hearing' but 'doing' that logosnow correlated, in good Stoic fashion, with a 'perfect law of freedom' (JacksonMcCabe 2010: 135-54). The text moves from a warning about the self-deception of 'merely hearing' to an insistence on the importance of 'doing' that logos, particularly in order to produce the erga that lead to 'blessedness' (1.25,

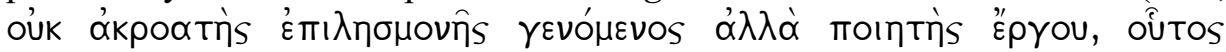

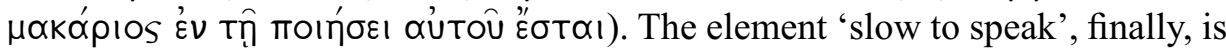
picked up in 1.26 with yet another caution regarding self-deception: this time, considering oneself to have an effective piety $(\theta \rho \eta \sigma K \varepsilon i \alpha)$ even if one does not 'bridle the tongue'. The unit as a whole is rounded off with a broad definition of

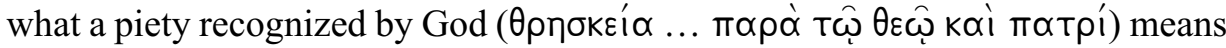
in a positive sense, namely, active concern for the most socio-economically vulnerable ('orphans and widows') while 'keeping yourself untainted by the world' (1.27).

In line with his thesis, of course, Dibelius treated 1.19-27 as an isolated unit, wholly unrelated both to what precedes and to what follows it. Speculating that 1.19 was taken from a collection of 'other, similarly structured sayings', he expressed 'relative certainty' that it was selected merely for its 'quick to hear' element. The elaboration of 'slow to anger', he suggested, was probably included only because it was already part of the tradition; and the author 'threw in' the warning about bridling the tongue simply for the sake of completeness,

22. Cf. Lucian, Dem. 51 (Macleod 1972: 55), where advice on the best way to exercise authority is summed up pithily as 'Don't lose your temper ... and say little while doing much listening [åop 
even though he did 'not want to talk about "speaking" at all' (Dibelius 1988: 108-109, 111).

Here again Dibelius's speculative interpretation is based more on his a priori assumption of a 'haphazard collector' model of authorship than anything found directly in the text itself. As he himself realized (1988: 109), 1.19 reads quite naturally as a statement of the practical consequences of what has preceded, at least for those uncommitted to his model: 'Know this, my beloved brothers, and let each person be quick to hear, slow to speak, and slow to anger' (1.19) ${ }^{23}$ It is all the more significant, then, that a concept of logos, introduced at the climactic end of the preceding discussion of temptation, features centrally as the three elements of 1.19 are unfolded in 1.19-27: explicitly in both 'slow to anger' and 'quick to hear', and implicitly in 'slow to speak'. ${ }^{24}$

The connection between 1.2-18 and 1.19-27 is reinforced by the continuation in the latter of several additional key themes of the former. The relationship between eschatological 'blessedness' and erga assumed in 1.25 is fundamental to the treatment of temptation in 1.2-18 (esp. 1.2-4, 12). The repeated warnings about self-deception in 1.22 and 1.26 recall the explicit (1.16) and implicit (1.7) such warnings in the preceding discussion of temptation, and play into that characteristic 'emphasis on proper understanding' that, as Johnson (1995: 175-76) has perceptively observed, 'most sets [Jas 1] apart' from the remainder of the letter. ${ }^{25}$ The distinction between 'human anger' and 'God's righteousness' in 1.20 similarly resonates with the preceding contrast between the deceptive, sin-

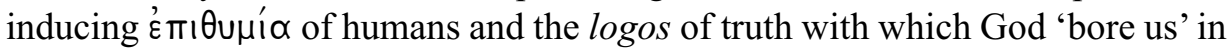
1.13-18.

In short, Jas 1.19-27, while clearly developed as a distinct unit of text, is scarcely devoid of meaningful connection to what precedes it. On the contrary, it pushes the text forward. After presenting a general account of the problem of temptation by desire (1.2-18), Jas 1.19-27 turns to the practical implications of the birth with logos cited at its close. To this end, the author invokes as a framing device a proverbial grouping of 'quick to hear', 'slow to speak' and 'slow to anger' in order to articulate more specifically what it means to live properly with respect to that logos, namely, doing the erga associated with the 'law of freedom', bridling the tongue, and manifesting a gentle disposition. Strikingly, these will turn out to be the central themes, respectively, of the three sections that follow in the main body of the letter $(2.1-26 ; 3.1-12 ; 3.13-4.10)$.

23. Dibelius (1988: 109) rejects this as 'not necessary'.

24. Cf. Jas 3.2, where bridling the tongue is correlated with not stumbling \& $v \lambda$ ó $\omega$; further Jackson-McCabe 2010: 224-30.

25. Johnson (1995: 175-76) notes that 'in the first 27 verses, there are some 17 terms touching on one aspect of knowing or another. In the remaining 81 verses, terms of knowledge occur only 7 more times'. The philosophical context of this emphasis is helpfully illuminated by Kloppenborg 2010. 


\section{James I.19-27 and 2.1-4.12}

As noted above, Dibelius speculated that Jas 1.19(-20) had initially belonged to an earlier collection, and was selected for inclusion in James solely for its 'doing' idea. If this imaginative reconstruction vividly illustrates the composition model that Dibelius assumes for the letter, it also highlights just how much the resultant hermeneutic requires the reader to ignore about the actual text. This goes not only for the relationship of 1.19-27 to what precedes it, but also for its relationship to what follows it. Dibelius's claim that the writer merely 'threw in' the elaboration of 'slow to speak' despite "not want[ing] to talk about "speaking" at all' (1988: 108-109, 111) is particularly astonishing given that control of speech will come to form the central theme of one of the so-called 'treatises' that Dibelius had himself identified as the core of text (3.1-12). Analogous verbal and thematic correspondences between the elaborations of 'quick to hear' and 'slow to anger' in 1.19-27 and the other major sections in the letter body, in fact, helpfully illuminate the underlying organization of the letter as a whole. ${ }^{26}$ The threepart grouping around which 1.19-27 is built is clearly traditional; but the use of tradition in this case is indicative of rhetorical invention, not a rote mining of written sources.

\section{James 1.26 and $3.1-12$}

The delineation of Jas 3.1-12 as a distinct section is entirely non-controversial. ${ }^{27}$ Equally obvious (to virtually everyone but Dibelius) is the connection that exists between this section and the elaboration of 'slow to speak' in 1.19-27. James 1.26 develops this element of the three-part grouping of 1.19 specifically in terms of 'bridling the tongue' ( $\chi \alpha \lambda ı \alpha \gamma \omega \gamma \hat{\omega} \nu \gamma \lambda \hat{\omega} \sigma \sigma \alpha v)$, and the subsequent treatment of speech in 3.1-12 is developed around precisely these two terms. The section begins by explaining its remarkable opening declaration that 'one who

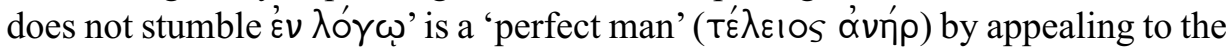
idea of 'bridling': he is perfect insofar as not stumbling év $\lambda o ́ \gamma \omega$ also implies an

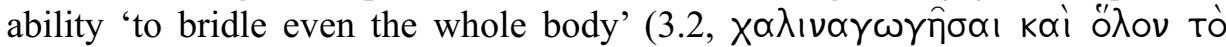
$\sigma \hat{\omega} \mu \alpha) .{ }^{28}$ This image of the bridle is then given a more vivid illustration in order to further the point: 'if bridles [Toùs $x \propto \lambda ı$ voús] are placed into the mouths of horses in order to persuade them, we lead also their whole bodies [kai ö $\lambda$ ov tò

26. For a similar, if rather more impressionistic, interpretation, see Pfeiffer 1850, esp. 167-78.

27. See esp. Watson 1993b; also Dibelius 1988: 181-82; Bauckham 1999: 64, and virtually all interpreters of the letter.

28. The seeming disjuncture between Jas 3.2 and the letter's otherwise emphatic insistence on the importance of deeds is registered by Johnson (1995: 256). The key to resolving the apparent tension, however, lies less in seeing speech itself as a 'work' (so Johnson) than in the anthropological assumptions attending the text's logos concept; see Jackson-McCabe 2010: 224-30. 
$\sigma \hat{\omega} \mu \propto \propto \cup \cup \bar{\tau} \nu$ ]' (3.3). After invoking the further analogy of the rudder (3.4), the text proceeds to bring the point to bear specifically on 'the tongue' $(3.5$, oút $\omega$ s

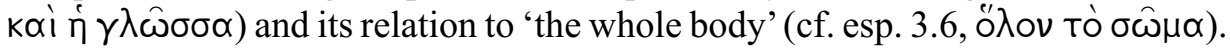
The remainder of the section is dominated by a series of explicit assertions about 'the tongue': 'the tongue is a fire' (3.6, $\dot{\eta} \gamma \lambda \hat{\omega} \sigma \sigma \alpha$ mûp); 'the tongue has been set

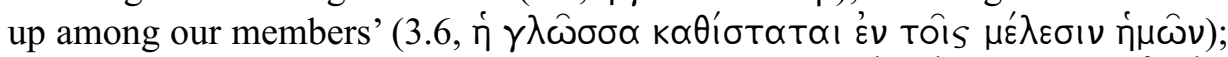

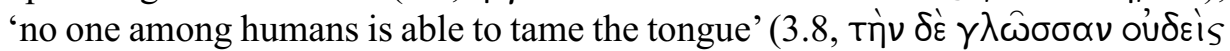

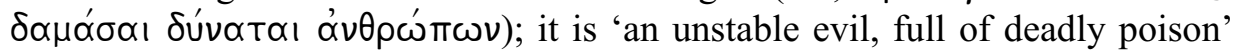

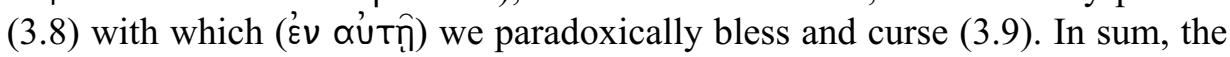
elaboration of 'slow to speak' in 1.26 serves to introduce and anticipate the two key themes around which the subsequent treatment of control of speech will be built in 3.1-12.

\section{James I.22-25 and James 2}

A similar pattern of correspondences exists between the elaboration of 'quick to hear' in 1.22-25 and the widely acknowledged two-part section of Jas $2 .{ }^{29}$ In this case the correspondence is underlined all the more by the fact that $1.22-25$ is only minimally concerned with the actual subject of the traditional admonition: 'quick to hear' serves as little more than a jumping off point for the text's real concern, which is 'doing'- -specifically the doing of that logos $(1.22$, попाтаi

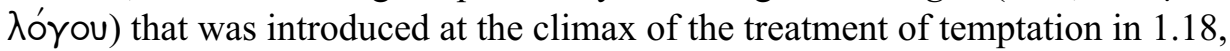
that was identified specifically as 'the implanted logos that is able to save your souls' in the elaboration of 'slow to anger' in 1.21, and that will now be closely

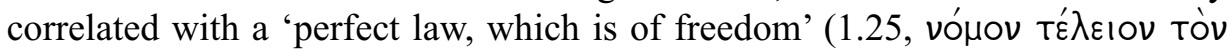
$T \hat{T} S \dot{\varepsilon} \lambda \varepsilon \cup \theta \varepsilon \rho i \alpha s)$. The central claim of 1.22-25 is that it is precisely attention to this 'law of freedom' that will make one the sort of 'ergon-doer' (moıntis हैpyou) who-as the treatment of temptation in 1.2-18 had already established

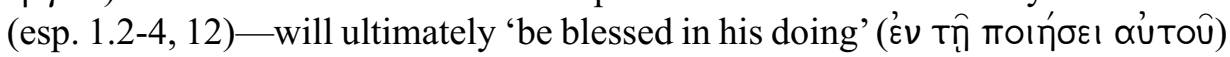
(1.25).

Once again the key terms around which the elaboration of an element of the three-part admonition is built in 1.19-27 anticipate the central themes around which a subsequent section of the letter will also be built. James 2 represents a two-part discussion of the relationship of faith to action, particularly where treatment of the poor is concerned. Where 2.1-13 argues that 'the faith of our Lord Jesus Christ' is incompatible specifically with acts of partiality against the poor, 2.14-26 generalizes out to a broader point about the uselessness of faith unaccompanied by action more generally — albeit once again with treatment of the

29. For the interpretation of Jas 2 as a single, two-part unit, see esp. Watson 1993a and, among many others, Johnson 1995: 218-19; Thurén 1995: 278-80; Cheung 2003: 72. 
poor as prime illustration (2.15-16) ${ }^{30}$ What is particularly striking in the present context is how each half of the section centers on a concept introduced in 1.2225. James 2.1-13 does not simply deal with partiality as such, but partiality specifically as a concrete example of 'keeping the whole law' (2.8-11) and thus 'acting'-i.e., 'doing', по।' $\omega$ —in a manner that accords with the 'law of free-

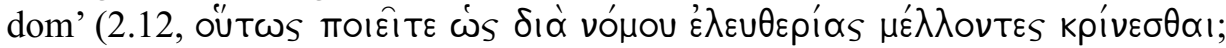

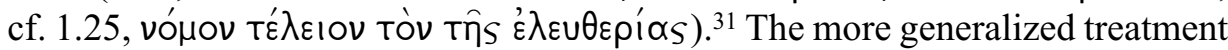
of the matter in 2.14-26, on the other hand, is framed as the relation of faith

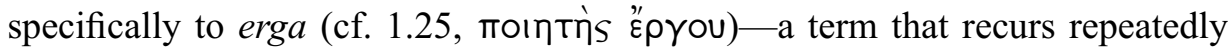
throughout the section $(2.14 .17,18[3 \times], 20,21,22[2 \times], 24,25,26)$, much as 'tongue' does in the second half of 3.1-12.

\section{James I.20-2I and 3.13-4.10}

It is clear by all accounts that the treatment of 'bridling the tongue' ends at 3.12. The structure of the lines that follow in 3.13-4.12, however, has been subject to various interpretations. The address to the 'brothers' that frequently opens new sections in the letter is in this case absent, and will appear again only in 4.11. James 3.13 also directly invokes the audience, but now with a challenge to them in the form of a rhetorical question: 'Who is wise and understanding among you? Let him show through virtuous behavior his erga in a wise gentleness.' A similar question is found in 4.1: 'Whence come wars and whence battles among you?' Bauckham (1999: 64-66), keying on these formal features, concludes that 3.1318, 4.1-10 and 4.11-12 are intended to be read entirely separately: three more of the various 'self-contained entities' he takes as making up the letter as a whole. Dibelius (1988: 207-208), on the other hand, recognizing the thematic continuity between 3.13-18 and 4.1-12, interpreted the entire passage as a single group of sayings on 'Contentiousness'. 32

The use of challenging rhetorical questions in both 3.13 and 4.1 is indeed striking. But contrary to Bauckham, this repetition of a convicting question to those 'among you' ( $\varepsilon v$ úfiv) does as much to unify 3.13-4.10 as a distinct unit of text as to signal a transition within it. ${ }^{33}$ The familial relationship that has to this point emphatically structured the author-audience relationship in the letter now begins to recede into the background. Indeed, by 4.4 the usual framing of the audience as 'brothers' has been fully eclipsed by convicting, distancing addresses

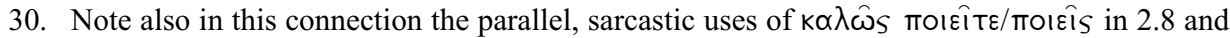
2.19 - the latter regarding love of God, and the former regarding love of neighbor (JacksonMcCabe 2010: 174-76).

31. See further Jackson-McCabe 2010: 154-85.

32. Similarly Pfeiffer (1850: 177), who considers 4.11-12 to be a continuation of the treatment of óprí in 3.13-4.10.

33. Compare the repeated $\alpha^{\prime} \gamma \eta \nu \hat{v} \nu$ in 4.13 and 5.1. 
to them as 'adulterers' (4.4), 'sinners' (4.8) and díuxo। (4.8; cf. 1.6-8) in what is thereby clearly marked as a distinct rhetorical highpoint in the letter (cf. Varner 2011). ${ }^{34}$

This formal analysis of the section as a rhetorical unit, moreover, is strongly reinforced by examination of its content. Luke Timothy Johnson (1983: 332) has demonstrated convincingly that 3.13-4.10 represents a unified 'call to conversion with two major parts: $3: 13-4: 6$ sets up an indictment, to which 4:7-10 responds', namely, with a demand for purification and repentance. ${ }^{35}$ In fact the logical coherence of the whole section, Johnson (1983) shows, is readily discernible in light of the Hellenistic topos of 'envy' ( $\phi \theta$ óvos).

This delineation of 3.13-4.10 as a third coherent section in the body of the letter is all the more significant in the present context, since it shows much the same relationship to the elaboration of 'slow to anger' in Jas 1.20-21 that Jas 2 and 3.1-12 have, respectively, with 'quick to hear' and 'slow to speak'. ${ }^{36}$ Here again the key terms and themes defining a two-part section in the body of the letter are anticipated by 1.19-27. In 1.20-21, a flat declaration that human anger

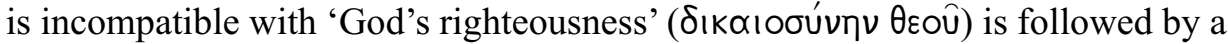

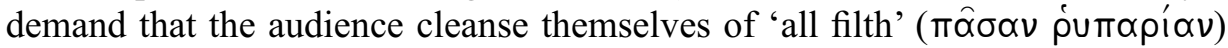

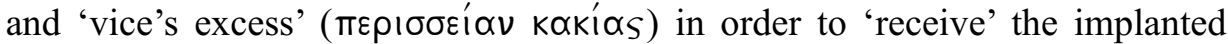
logos with a disposition characterized instead by gentleness ('ย The whole of Jas 3.13-4.10 is introduced precisely as a challenge to anyone who might claim wisdom to demonstrate it specifically with a wise gentleness (3.13,

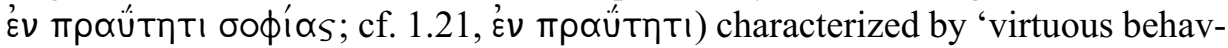

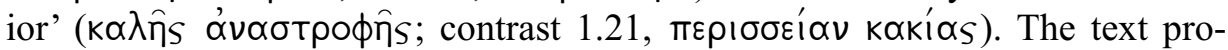
ceeds to distinguish a wisdom that is 'earthly', 'demonic' and characterized by social discord and 'every foul deed' (4.15-16), from one that is 'from above' ( $\propto$ ' $v \omega \theta \varepsilon v)$, that is pure and peaceful (3.17), and that issues, in a word, in the 'fruit

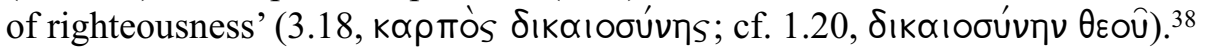

34. Every other direct address of the audience in the letter body frames them simply as 'brothers' or even 'beloved brothers', even when chastising them; see $2.1,5,14 ; 3.1,10$. The address of an individual interlocutor as 'foolish man' in 2.20 is a partial exception. Jas 4.13-17 and 5.1-6 are not addressed to the audience as such; see below.

35. Johnson (1983: 332) notes that ' $[t]$ he connective oûv in 4:7 indicates that the series of imperatives (and assurances) is based on what preceded it'.

36. Noted, but to no effect, already by Dibelius (1988: 109): 'these very themes [i.e., the tongue and anger in 1.19-27] are treated in more detail later on in $\mathrm{Ja}[\mathrm{me}] \mathrm{s} . .$. anger (at least by implication) in the admonition to "meekness" (

37. The notion that something already 'implanted' is nonetheless to be 'received' is a problem on any interpretation of ' in any case have the force of ongoing 'receptivity' rather than initial 'reception'.

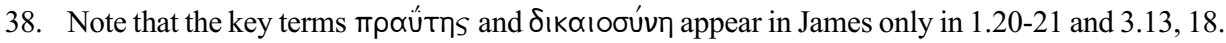


As in 1.20, this contrast between an all-too-human bitterness $(1.20$, ópүì

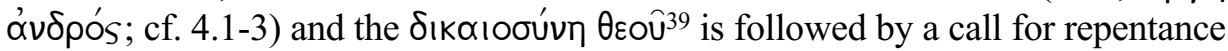
that in both passages is pictured particularly with images of dirtiness and impurity. If those characterized by oprn' in 1.20-21 are to remove 'all filth'

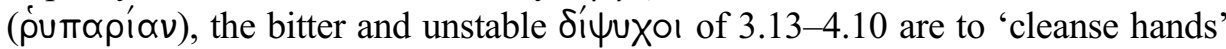

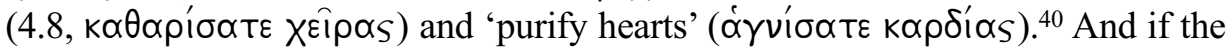
latter purification concerns above all a disposition toward sating one's own desires (4.1-3), it is all the more significant that the removal of 'all filth' in 1.21 is key to a proper response to the " opposition to ' $\varepsilon$ m $\theta u \mu^{\prime} \alpha$ in the account of temptation in 1.2-18. Indeed, the analysis of the sort of 'bitter jealousy' that leads to social conflict and violence in 4.1-6 centers largely on the same question that was also central to the account of temptation in Jas 1: how to - and how not to - acquire things from the providential deity.

You desire $[\dot{\varepsilon} \pi|\theta u \mu \varepsilon| \tau \varepsilon]$ and you do not have ... you are jealous and you are not able to acquire ... You do not have because you do not ask; you ask and do not receive, which means you are asking viciously [ $\kappa \alpha \kappa \omega \hat{s}]$, in order that you might sate your

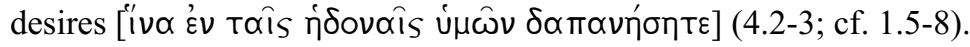

Invoking Prov. 3.34, the text frames such self-seeking as 'arrogance' that God will actively resist, while 'giving a gift' instead to 'the humble' (4.6, тапєıvoîs $\delta$ ' $\delta i \delta \omega \sigma I v ~ X \alpha ́ \rho ı v)$. The repentance sought is thus framed not only as a 'cleansing'

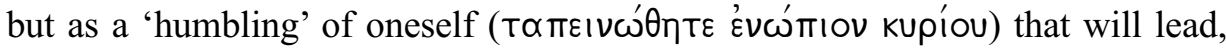
paradoxically, to a divine exaltation (4.10; cf. 1.9-11).

Taken together, then, 1.20-21 and 3.13-4.10 help to underscore a logos/desire dichotomy that is in fact a generative problem in the letter as a whole, one intimately related to its other key themes: arrogance and humility; the importance of faith in God's role as providential giver; law, erga, and socio-economic concerns; eschatological humiliation and exaltation; and even control of speech. It is a problem that Jas 1.2-18, appropriately enough, frames generally at the outset as a matter of temptation.

\section{James 4. I I-I 2 as Integrative Summary}

As noted above, the relation of Jas 4.11-12 to what precedes and follows it has been variously interpreted. Johnson (1995: 291-92), correctly sensing a closure to the call to conversion in 4.10 , considers 4.11 to represent 'some sort of starting point' ${ }^{41}$ The return to the warmer, more usual address to the audience as 'broth-

39. Cf. in this respect the contrast between 'earthly' wisdom and the wisdom that is $\alpha$ ' $v \omega \theta \varepsilon v-a$

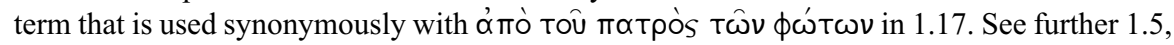
where any who lack ooфía are told to ask for it from God.

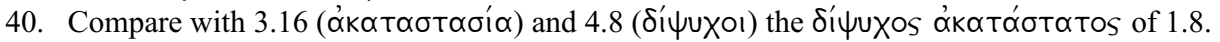

41. Johnson (1995: 291-92) points out in this connection that negative commands (cf. 4.11, $\mu$ in $\kappa \propto T \alpha \lambda \alpha \lambda \varepsilon \hat{\imath} \tau)$ sometimes begin new sections in the letter; compare 2.1 and 3.1. 
ers' for the first time since the treatment of the tongue $(3.1,10)$ underscores the point: having been rhetorically cast out and convicted as 'sinners' in 3.13-4.10, the audience is now brought back into the fold.

Johnson's (1995: 291-92) location of 4.11-12 at the head of a new section running from 4.11-5.6, however, is rather less compelling. The distinctive repetition of $\alpha^{\prime} \gamma \eta \nu \cup \hat{v}$ in 4.13 and 5.1 sends a clear textual signal that 4.13-17 and 5.1-6 are to be taken as a set; and, as I will suggest momentarily, that set serves a distinct rhetorical function as the penultimate section of the letter. That 4.11-12 also belongs to it is far from obvious both formally and functionally.

If formally distinct both from what precedes it and what follows it, however, 4.11-12 is scarcely unrelated thematically to its context. The highly compressed equation of slandering and judging the brothers with slandering and judging the law in 4.11 not only follows naturally on the treatment of 'wise gentleness' in 3.13-4.10, but serves to tie it together with key themes of the preceding two sections as well. The opening admonition $\mu \eta \dot{\eta} \kappa \alpha \tau \alpha \lambda \alpha \lambda \varepsilon \hat{\imath} \tau \varepsilon \dot{\alpha} \lambda \lambda \eta \dot{\lambda} \lambda \omega \nu$ reintroduces the theme of speech of 3.1-12, where the treatment of 'bridling the tongue' had itself ultimately built toward a particular application involving social conflict: 'with it we bless the Lord and Father; and with it we curse the people made in the likeness of God ... my brothers, things should not be this way' (3.9-10). Similarly, the equation of judging ( $k$ ív $v \omega$ ) one's 'brother' with 'judging the law', together with the warning that one who acts thus is not a moınтìs vómou, recalls the treatment of 'law' and 'doing' in both Jas 2 and the closely related 1.22-25. Indeed, the portrayal in Jas 2 of those who show partiality precisely as 'judges with evil cal-

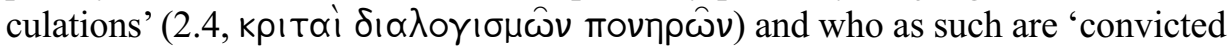
by the law as transgressors' (2.9) goes a long way toward clarifying the otherwise opaque logic underlying the equation of judging brothers with judging the law in 4.11. ${ }^{42}$ The emphatic assertion regarding the 'one lawgiver and judge' in this connection in 4.12 similarly reprises the pointed invocation of Deut. 6.4 in Jas 2.19.43

The description of that 'lawgiver and judge' specifically as one 'who is able to

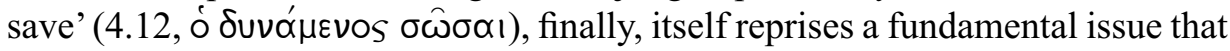
surfaces repeatedly through the letter, namely, who or what is 'able to save'. The

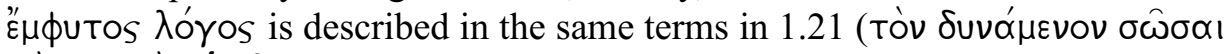

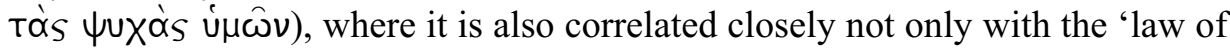
freedom', but with erga (1.22-25). Not coincidentally, this concern becomes a central theme in the corresponding treatment of the law and erga in Jas 2, where

42. The theme of 'judging' is integral to that of partiality (Jackson-McCabe 2010: 157-64). Also noteworthy here is the similar juxtaposition of the prohibition of partiality in Lev. 19.15 with an apparent prohibition of slander in Lev. 19.16; see Johnson 1995: 293, and note as well in this connection the sudden substitution in 4.12 of $\pi \lambda \eta$ oíos for the letter's more usual 'brother', with which compare Lev. 19.16, 17, 18.

43. See above n. 30 . 


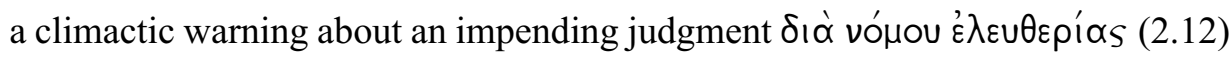
is followed immediately by the question of whether faith apart from erga is 'able

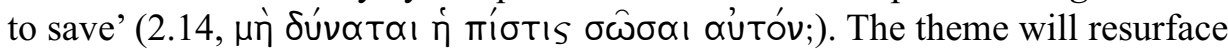
in the closing lines of the letter, where the one who turns the wandering sinner from the way of error to the way of truth is said to 'save his soul' $(5.20, \sigma \omega \sigma \varepsilon$ ।

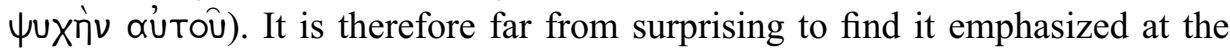
close of the main body of the letter in 4.11-12 as well.

In sum, the use of a direct address to the 'brothers' in 4.11, standing between a series of climactic, quasi-prophetic addresses to the audience as 'adulterers' within a call to repentance (4.4-10), on the one hand, and a pair of chiding 'come now' (व’ $\gamma \eta v \hat{v} v)$ addresses to particular groups with ambiguous relationships to the audience, on the other (4.13-17; 5.1-6), ${ }^{44}$ is marked off as a distinct rhetorical moment in the text. Nonetheless, what is most distinctive about 4.11-12 from a thematic point of view is precisely its highly compressed integration of key themes treated in the preceding three units: using speech (cf. 3.1-12) as a tool of social conflict (cf. 3.13-4.10) represents a failure to become a 'law-doer', and is thus to put one's salvation in jeopardy in light of the coming divine judgment by the lawgiver (cf. Jas 2). By tying these themes together, 4.11-12 serves to round off the three-unit section in 2.1-4.10.

\section{Summary:James I.19-27 and 2.1-4.12}

The preceding analysis has shown a series of close correlations between the unfolding of each element of a proverbial grouping of 'quick to hear', 'slow to speak' and 'slow to anger' in 1.19-27 and the three units that follow in 2.1-4.10. Much as 1.27 serves to round off 1.19-27 with a general, concluding statement on 'true piety', 4.11-12 serves a similar concluding function by drawing together important elements from each of the preceding three sections. The structural relationships, with key verbal and thematic echoes, can be summarized as follows:

\begin{tabular}{|c|c|c|c|c|}
\hline 1.19 & $1.20-26$ & 1.27 & $2.1-4.10$ & $4.11-12$ \\
\hline $\begin{array}{l}\text { (i) quick to } \\
\text { hear }\end{array}$ & 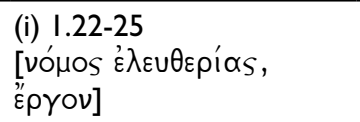 & $\begin{array}{l}\text { Conclusion: } \\
\text { 'true piety' }\end{array}$ & $\begin{array}{l}\text { (i) } 2.1-26 \\
{\left[\nu{ }^{\prime} \mu{ }^{\prime} \varepsilon \lambda \varepsilon \cup \theta \varepsilon \rho i \alpha_{S},\right.} \\
\varepsilon \rho \gamma \alpha]\end{array}$ & $\begin{array}{l}\text { Summation:(i) } \\
+ \text { (ii) }+ \text { (iii) }\end{array}$ \\
\hline $\begin{array}{l}\text { (ii) slow to } \\
\text { speak }\end{array}$ & $\begin{array}{l}\text { (ii) } 1.26 \\
{\left[x \alpha \lambda ı v \alpha \gamma \omega \gamma^{\prime} \dot{ } \omega\right.} \\
\gamma \lambda \omega \hat{\omega} \sigma \sigma \alpha]\end{array}$ & & 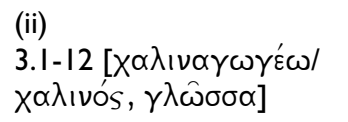 & \\
\hline $\begin{array}{l}\text { (iii) slow to } \\
\text { anger }\end{array}$ & 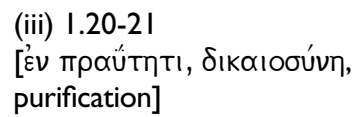 & & 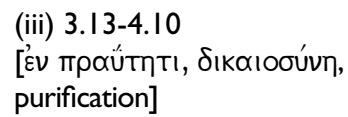 & \\
\hline
\end{tabular}

44. On 4.13-17 and 5.1-6, see immediately below. 
Seen in this light, 1.19-27 functions in a manner broadly analogous to what Cicero, in his On Invention, called a partitio - namely, the part of a discourse where 'the matters which we intend to discuss are briefly set forth in a methodical way'. ${ }^{45}$ The relationship in any case suggests that the three sections that make up 2.1-4.12 represent the main body of the letter. Formal, functional, and thematic analysis of the remaining units of the text strongly reinforce this conclusion.

\section{James 4. I 3-5.20}

As is widely recognized, Jas $4.13-5.20$ falls naturally into two distinct units: 4.13-5.6 on one hand and 5.7-20 on the other. I deal with each briefly in turn.

\section{James 4. 13-5.6:Apostrophes against the Arrogant}

As mentioned above, there are strong textual signals marking Jas 4.13-5.6 off as a two-part unit. The clearest of these is the repetition of the distinctive opening 'come now' ( $\left.\alpha^{\prime} \gamma \eta v \hat{v} v\right)$ in 4.13 and 5.6. Equally important is the way these openings signal shifts to new implied audiences with rather ambiguous relationships to the 'brothers': those who make plans to travel and profit without an inshallahstyle caveat in 4.13-17 and, more baldly, 'the rich' in 5.1-6. The result is a quite distinctive unit in the letter, where the voice of the author speaks as if over the shoulder of the 'brothers', who have thus temporarily become witnesses to a rebuke rather than direct recipients of it. ${ }^{46}$ Particularly coming, as it does, after the main body as the penultimate section of the letter, 4.13-5.6 can be fruitfully compared at a functional level with the part of speech that Cicero calls an indignatio, namely, a portion of the peroration designed to 'excit[e] ... indignation or

45. De Inventione 1.31 (LCL), calling this the 'second form' of partition. Cicero, unfortunately, limits his discussion of the partitio to points that are relevant to oratorical practice, noting that 'there are other rules' for its use in philosophical contexts that he does not address (1.33). See further Quintilian 4.5.1-28, who notes (albeit with strong reservations) the view of some that the 'partition should not extend beyond the length of three propositions' (4.5.3 [LCL]). If Jas 1.19-27 passes muster in this respect, Quintilian would likely have been critical of James insofar as Quintilian considers 'treat[ing] your points in an order different from that which was assigned them in your proposition' to be 'the worst fault of all' (4.5.28). While the ordering of themes in James's letter body correlates with that of the three-part admonition in 1.19, the treatment of them in 1.19-26 places the (longer) elaboration of 'quick to hear' in the center position, perhaps to emphasize it.

46. Cf. the diatribal engagement with the 'foolish man' in 1.20; the collective audiences in 4.135.6 , however, are more mute targets of quasi-prophetic monologues than participants in a pedagogical dialogue. 
ill-will against the opponent', and which thus 'results in arousing great hatred against some person, or violent offence at some action' ${ }^{47}$

James, of course, is a letter directed at fellow members of a cult group, not a speech before a court of law. The intention here is thus not to whip up emotions against a particular accused individual, but against a class of people the author here and elsewhere clearly wishes to definitively mark as 'other', namely 'the rich' (cf. 1.10-11; 2.6), and more generally against the sort of self-seeking, economically motivated behaviors by which he wishes to define them.

The section as a whole moves from a relatively gentle chiding of a form of behavior - an 'arrogant' (4.16) self-interest that is insufficiently attentive to the will of the deity - to a stunningly harsh denunciation of a class of people, 'the rich', who represent the embodiment of that behavior. If 5.1-6 fairly revels in anticipation of the 'slaughter' that awaits them, the aim is less to spur these 'rich' to repentance than to unify 'the brothers' around a negative assessment of them as an ostracized class - an aim helpfully illuminated by the very practical concern, expressed in Jas 2, that the intended audience is actually in the habit of actively courting such people (2.2-7). ${ }^{48}$ This is all the more important to the rhetoric of the letter insofar as these 'rich', as mentioned above, might otherwise seem to belie its key point regarding God's providence for the humble in particular (4.6), that is his elect 'poor' (2.5). As in 1.9-11, emphasis is thus placed on the temporary nature of their present standing, here developed more explicitly in light of an impending (and rather brutal) eschatological reversal. The device is all the more effective given its placement after an address to an unlabeled group of any and all who exhibit economic self-interest without regard for the will of God - a type with which 'the brothers' presumably could more easily, if uncomfortably, identify. The movement from 4.13-17 to 5.1-6 serves to put such mundane 'arrogance' on a continuum with that of 'the rich', thus impressing upon all those who aspire to wealth, or who would cultivate relationships with wealthy benefactors, the dangerous end of that path.

\section{James 5.7-20: Concluding Exhortation to Humble Endurance}

James 5.7, with its resumption of a direct address to the 'brothers', marks another significant transition in the letter. The authorial gaze now shifts firmly back to the primary audience as kin group, where it will stay, emphatically, through the

47. Cicero, Inv. 98, 100. Interestingly, several of the particular topics that Cicero recommends to achieve this effect are evident in this section of James, including an appeal to the authority and interests of 'the immortal gods' (102; cf. Jas 4.15; 5.4), and most especially indignation regarding a deed done 'by force and violence or by the influence of riches' that is 'at variance with law and equity' (102; cf. esp. Jas 5.4).

48. On patronage as an underlying concern of 2.1-13 and in the letter more generally, see Kloppenborg 1999 and Batten 2010. 
remainder of the letter: the direct address to 'the brothers' occurs a remarkable five times over the course of 5.7-20. Indeed, the unusual repetition of this device over such a short span of text in this case actually provides a unifying element to the section as the letter's conclusion. ${ }^{49}$

To be sure, 5.7-20 does seem to present a sequence of summary admonitions rather than to develop a tightly constructed argument. The text moves from an exhortation to endurance (5.7-11) to a prohibition of swearing (5.12) to a discussion of the power of prayer (5.13-18) to the results of turning 'sinners' from 'deception' to 'the truth' (5.19-20). Even here, however, the lack of coherence should not be overstated. The various concerns raised in this concluding section are in fact closely intertwined within the discourse of this text-a fact underscored not least by their similar juxtaposition in the letter's introductory section in Jas 1.50

The section opens in 5.7-11 with a reprisal of the key introductory theme of endurance (ن்ouoví). ${ }^{51}$ As elsewhere in the concluding section (5.12, 19-20; perhaps also 5.15), the eschatological horizon comes front and center, with the issue now framed specifically as patient endurance in light of the rapidly approaching parousia $(5.7,8,9)$ and its attendant slaughter of 'the rich' (cf. 5.1-6 and 1.9-11). ${ }^{52}$ Much as in Jas 1.5-8, this encouragement to endure is fol-

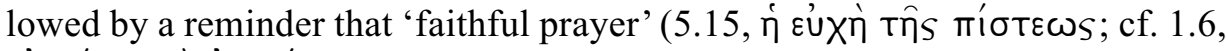

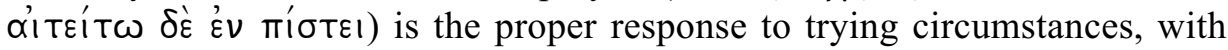
emphasis once again on the deity's providence for those who ask in this way. Both the point about endurance and that about prayer are further bolstered in the concluding section by heroic illustrations from Israel's past $(5.10,11$, 17-18).

The intervening and particularly emphatic ( swearing in 5.12, while not reprising any specific theme of Jas 1 , is scarcely unrelated either to the general instruction of James or to the themes of endurance and prayer in particular. While obviously reminiscent of the saying found in Matthew's Sermon on the Mount (Mt. 5.34-37), its more immediate resonance within the text lies with the so-called conditio Jacobea (4.15) underlying the apostrophe against the arrogant in 4.13-17. As such, 5.12 underscores the letter's more general insistence on a thoroughgoing humility that places the will of the deity always and emphatically before one's own individual

49. Elsewhere it is used no more than three times in a single section, and then only in the substantially longer Jas 1 and Jas 2. It occurs twice in 3.1-12, and not at all in 3.13-4.10 or 4.13-5.6.

50. The relationship of Jas 5.7-20 to Jas 1 has been frequently noted; e.g., Fry 1978: 429-30; Wuellner 1978: 43-44; Baasland 1982: 122; Reese 1982: 84; Frankemölle 1990: 175-84; Crotty 1992: 51; Thurén 1995: 269, 274; Cheung 2003: 68-71.

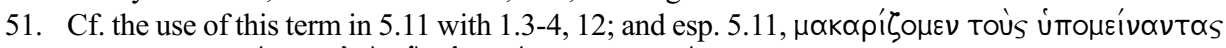

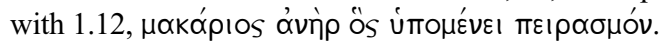

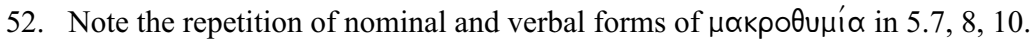


intentions and desires. It is precisely such faithful humility that turns to God in prayer - not to the pursuit of desire - in situations of need, that will thus endure when faced with various kinds of temptation, and that, regardless of present appearances to the contrary, will ultimately be rewarded with a divine exaltation (cf. $1.9 ; 4.10)$.

James 5.19-20, finally, invokes the 'two ways' that lay before one: deception

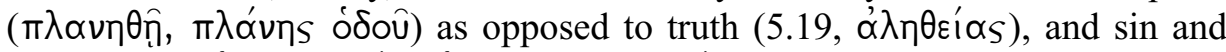

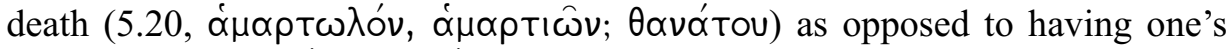

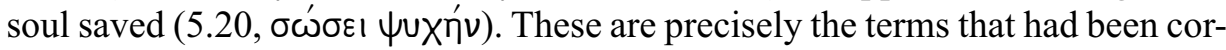
related with desire and logos, respectively, in Jas 1: deception (1.16,

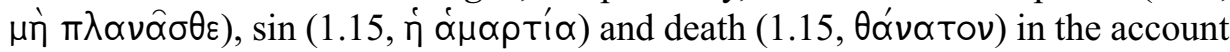
of desire's seductive power; and truth $\left(1.18, \lambda o^{\prime} \gamma \omega \alpha^{\prime} \lambda \eta \theta \varepsilon \varepsilon^{\prime} \alpha_{S}\right)$ and an ability to

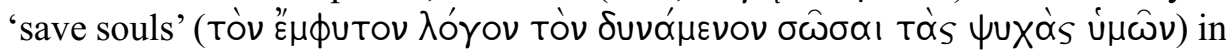
relation to the divinely given logos (cf. Crotty 1992: 46-47). The letter thus comes to an end with a re-articulation of the core dichotomy around which its whole instruction has been built. Here, however, the 'brothers' (5.19) are enjoined not so much to guard their own salvation as to help 'turn back' others among them who might themselves be straying from the path. This, one imagines, is precisely what the letter as a whole was intended to do; and the author concludes by encouraging his 'brothers' to join him in the task.

\section{Conclusion}

The letter of James is not a compendium of earlier traditions. It is a unified composition whose theological and literary coherence centers on a dichotomy between human desire and a divinely given logos correlated with God's law. The letter opens by identifying temptation-framed as a choice between pursuing one's own desires and relying on a provident God who 'bore us' with logos - as a central human problem with profound ethical and soteriological consequences (1.2-18). Invoking a bit of proverbial wisdom about the importance of being 'quick to hear', 'slow to speak' and 'slow to anger' as a framing device, it proceeds to introduce three practical implications of this problem (1.19-27) that will be addressed in the main body of the letter (2.1-4.12): doing law and erga (James 2 ), control of speech (3.1-12) and having a gentle disposition (3.13-4.10). The letter's exhortations are issued in light of a looming judgment according to divine law that promises an imminent and dramatic reversal in the fortunes of those 'rich' who arrogantly pursue their own schemes and the elect 'poor' who rely faithfully and humbly on the will and providence of the deity. These themes are reinforced in concluding sections that vilify self-serving economic behaviors and 'the rich' in particular (4.13-5.6), while encouraging the 'brothers' to endure in humble reliance on a provident God as they patiently await their anticipated reward (5.7-20). 


\section{References}

Baasland, Ernst

1982 'Der Jakobusbrief als neutestamentliche Weisheitsschrift', ST 36: 119-39.

1988 'Literarische Form, Thematik und geschichtliche Einordnung des Jakobusbriefes', $A N R W 2.25 .5$ : 3646-84.

1992 Jakobsbrevet (KNT, 16; Uppsala: EFS).

Bachman, E. Theodore

1960 Luther's Works. XXXV. Word and Sacrament I (Philadelphia: Muhlenberg).

Batten, Alicia J.

2009 What Are they Saying about the Letter of James? (New York: Paulist Press).

2010 Friendship and Benefaction in James (Emory Studies in Early Christianity, 15;

Blandford Forum: Deo).

Bauckham, Richard

1999 James: Wisdom of James, Disciple of Jesus the Sage (London: Routledge).

Burchard, Christoph

2000 Der Jakobusbrief (HNT, 15/1; Tübingen: Mohr Siebeck).

Cargal, Timothy B.

1993 Restoring the Diaspora: Discursive Structure and Purpose in the Epistle of James (SBLDS, 144; Atlanta: Scholars Press).

Cheung, Luke L.

2003 The Genre, Composition and Hermeneutics of the Epistle of James (Carlisle: Paternoster Press).

Crotty, Robert B.

1992 'The Literary Structure of the Letter of James', Australian Biblical Review 40: 45-57.

Davids, Peter H.

1980 'Theological Perspectives on the Epistle of James', JETS 23: 97-103.

1982 The Epistle of James: A Commentary on the Greek Text (NIGTC; Grand Rapids, MI: Eerdmans).

1988 'The Epistle of James in Modern Discussion', ANRW 2.25.5: 3621-45.

Dibelius, Martin

1921 Der Jakobusbrief (KEK, 15; Göttingen: Vandenhoeck \& Ruprecht).

1988 James: A Commentary on the Epistle of James (ed. H. Greeven; trans. M.A. Williams; Hermeneia; Philadelphia: Fortress Press).

Edgar, David H.

$2001 \quad H a s$ God not Chosen the Poor? The Social Setting of the Epistle of James (JSNTSup, 206; Sheffield: Sheffield Academic Press).

Elliott, John H.

1993 'The Epistle of James in Rhetorical and Social Scientific Perspective. HolinessWholeness and Patterns of Replication', BTB 23: 71-81. 
Francis, Fred O.

1970 'The Form and Function of the Opening and Closing Paragraphs of James and 1 John', ZNW 61: 110-26.

Frankemölle, Hubert

1990 'Das semantische Netz des Jakobusbriefes. Zur Einheit eines umstrittenen Briefes', BZ 34: 161-97.

Fry, Euan

1978 'The Testing of Faith: A Study of the Structure of the Book of James', BT 29: 427-35.

Jackson-McCabe, Matt

2003 'The Messiah Jesus in the Mythic World of James', JBL 122: 701-30.

2010 Logos and Law in the Letter of James: The Law of Nature, the Law of Moses, and the Law of Freedom (NovTSup, 100; Leiden: Brill, 2001; repr. Atlanta: Society of Biblical Literature).

Johnson, Luke Timothy

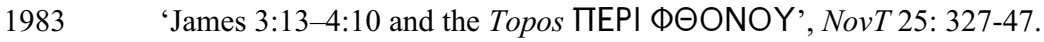

1995 The Letter of James: A New Translation with Introduction and Commentary (AB, 37a; New York: Doubleday).

Klein, Martin

1995 'Ein vollkommenes Werk': Vollkommenheit, Gesetz und Gericht als theologische Themen des Jakobusbriefes (BWANT, 139; Stuttgart: Kohlhammer).

Kloppenborg, John S.

1999 'Patronage Avoidance in James', HvTSt 55: 755-94.

2010 'James 1:2-15 and Hellenistic Psychagogy', NovT 52: 37-71.

Konradt, Matthias

1998 Christliche Existenz nach dem Jakobusbrief: Eine Studie zu seiner soteriologischen und ethischen Konzeption (SUNT, 22; Göttingen: Vandenhoeck \& Ruprecht).

1999 'Theologie in der "strohernen Epistel”: Ein Literaturbericht zu neueren Ansätzen in der Exegese des Jakobusbriefes', $V F$ 44: 54-78.

Lips, Hermann von

1990 Weisheitliche Traditionen im Neuen Testament (WMANT, 64; Munich: Neukirchener Verlag).

Macleod, M.D.

1972 Luciani Opera. Tomus I, Libelli 1-25 (Scriptorum Classicorum Bibliotheca Oxoniensis; Oxford: Clarendon Press).

Penner, Todd C.

1999 'The Epistle of James in Current Research', CurBS 7: 257-308.

Pfeiffer, E.

1850 'Der Zusammenhang des Jakobusbriefes', TSK 23: 163-80.

Reed, Jeffrey T. 
1997

'The Epistle', in S.E. Porter (ed.), Handbook of Classical Rhetoric in the Hellenistic Period, 330 B.C. - A.D. 400 (Leiden: Brill): 171-93.

Reese, James M.

1982 'The Exegete as Sage: Hearing the Message of James', BTB 12: 82-85.

Taylor, Mark E.

2004 'Recent Scholarship on the Structure of James', CBR 3: 86-115.

Taylor, Mark E. and George H. Guthrie

2006 'The Structure of James', $C B Q$ 68: 681-705.

Thurén, Lauri

1995 'Risky Rhetoric in James?', NovT 37: 262-84.

1997 'The General New Testament Writings', in S.E. Porter (ed.), Handbook of Classical Rhetoric in the Hellenistic Period, 330 B.C. - A.D. 400 (Leiden: Brill): 587607.

Tollefson, Kenneth D.

1997 'The Epistle of James as Dialectical Discourse', BTB 21: 62-69.

Tsuji, Manabu

1997 Glaube zwischen Vollkommenheit und Verweltlichung: Eine Untersuchung zur literarischen Gestalt und zur inhaltlichen Kohärenz des Jakobusbriefes (WUNT, 2/93; Tübingen: Mohr [Siebeck]).

Varner, William C.

2011 'The Main Theme and Structure of James', MSJ 22: 115-29.

Wachob, Wesley Hiram

2000 The Voice of Jesus in the Social Rhetoric of James (SNTSMS, 106; Cambridge: Cambridge University Press).

Walker, Donald Dale

2002 Paul's Offer of Leniency (2 Cor 10:1): Populist Ideology and Rhetoric in a Pauline Letter Fragment (WUNT, 2/152; Tübingen: Mohr Siebeck).

Watson, Duane F.

1993a 'James 2 in Light of Greco-Roman Schemes of Argumentation', NTS 39: 94-121.

1993b 'The Rhetoric of James 3:1-12 and a Classical Pattern of Argumentation', NovT 35: 48-64.

2007 'An Assessment of the Rhetoric and Rhetorical Analysis of the Letter of James', in R.L. Webb and J.S. Kloppenborg (eds.), Reading James with New Eyes (London: T\&T Clark): 99-120.

Wuellner, Wilhelm H.

1978 'Der Jakobusbrief im Licht der Rhetorik und Textpragmatik', LB 43: 5-66.

Post-print standardized by MSL Academic Endeavors, the imprint of the Michael Schwartz Library at Cleveland State University, 2017 